ЦИФРЛЫҚ ТЕХНОЛОГИЯЛАР НЕГІЗІНДЕ АӨК ЖАҢҒЫРТУ

МОДЕРНИЗАЦИЯ АПК НА ОСНОВЕ ЦИФРОВЫХ ТЕХНОЛОГИЙ

\title{
MODERNIZATION OF AIC BASED ON DIGITAL TECHNOLOGIES
}

\author{
Б.С. УТЕГУЛОВА \\ PhD докторы \\ Ж.К. ЖАРЫЛҚАСЫН ${ }^{2}$ \\ PhD докторанты \\ ${ }^{1}$ Абылай хан атындағы Қазақ халықаралық қатынастар және әлем тілдері универси- \\ теті, Алматы, Қазақстан \\ ${ }^{2}$ «Тұран» университеті, Алматы, Қазақстан \\ *bakhyt_u@mail.ru \\ Б.С. УТЕГУЛОВА \\ доктор $\mathrm{PhD}$ \\ Ж.К. ЖАРЫЛКАСЫН \\ докторант PhD \\ ${ }^{1}$ Казахский университет международных отношений и мировых языков \\ им. Абылай хана, Алматы, Казахстан \\ ${ }^{2}$ Университет «Туран», Алматы, Казахстан \\ B.S. UTEGULOVA ${ }^{1}$ \\ $P h D$ \\ ZH. ZHARYLKASSYN ${ }^{2}$ \\ PhD student \\ ${ }^{1}$ Kazakh Ablai Khan University of International Relations and World Languages, \\ Almaty, Kazakhstan \\ ${ }^{2}$ Turan University, Almaty, Kazakhstan
}

\begin{abstract}
Аңдатпа. Отандық АӨК-нің жұмыстың цифрлық форматына көшуінің негізгі алғышарттары көрсетілген. Агроөнеркәсіптік кешеннің дамуына цифрлық технологиялардың әсер ету векторлары қарастырылуда. Экономика салаларындағы цифрлық жаңғыртулар - бұл, ең алдымен, елдің көлік-логистикалық жүйесін автоматтандыру; аграрлық салада, өнеркәсіпте коммуникациялық процестерді пайдалану; электрондық сауда және цифрлық ақпараттың сақталуы мен қолжетімділігін қамтамасыз ету жүйелерін жақсарту, сондай-ақ "ақылды" қалаларды құру үшін осы әдістер мен тәсілдерді іске асыру арқылы жаңа индустрия құру. Авторлар цифрландыру - осы мақсаттарға қол жеткізудің ең перспективалы құралдарының бірі екенін атап өткен. Сонымен қатар, агробизнесте шешім қабылдауда оның кірістілігін арттыру, нарықтағы үлесін кеңейту, капиталдандырудың өсуі сияқты категорияларды басшылыққа алатындығын түсіну керек. Бұл бағытта цифрландыру одан әрі дамуды ынталандырудың бірі болып табылады, өйткені бәсекеге қабілетті нарықтарда болжамды тәуекелдің қолайлы деңгейімен кірістілікті арттыруды қамтамасыз етуге қабілетті кез келген шаралар зерделенуге және практикаға енгізуге жатады. Республиканың ауыл шаруашылығындағы тиімді, цифрлық технологиялардың ерекшеліктері талданған. Отандық аграрлық сектордың негізгі проблемасы ретінде төмен өнімділік пен жоғары шығындар айқындалды. Қазақстанның мемлекеттік саясаты инновациялық нанотехнологиялар бойынша құрылған ауыл шаруашылығы техникасының жетекші әлемдік брендтерін елімізге тартуға, оқшаулаудың объективті түрде орындалатын шарттарымен жергілікті өндірістерді қолдауға бағытталған. Ауыл шаруашылығы дақылдарының шығымдылығын, малдардың өнімділігін және еңбек өнімділігін арттыру, өндірістік шығындарды төмендету міндеттерін шешу үшін жоғары технологиялық әдістерді қолдану қажеттілігі туралы қорытынды жасалған.
\end{abstract}


Аннотация. Отражены ключевые предпосылки перехода отечественного АПК к цифровому формату работы. Рассматриваются векторы влияния цифровых технологий на развитие агропромышленного комплекса. Цифровые преобразования в отраслях экономики - это, прежде всего, создание новой индустрии путем автоматизации транспортно-логистической системы страны; использования коммуникационных процессов в аграрной сфере, промышленности; электронной торговли и улучшения систем обеспечения сохранности и доступности цифровой информации, а также реализации этих методов и способов для создания «умных» городов. Авторы отмечают, что цифровизация - один из наиболее перспективных инструментов достижения этих целей. Помимо этого, следует понимать, что агробизнес в принятии решений руководствуется такими категориями, как повышение его рентабельности, расширение своей доли рынка, рост капитализации. В этом направлении цифровизация является одним из стимулов дальнейшего развития, ведь на конкурентных рынках любые меры, способные обеспечить увеличение прибыльности с приемлемым уровнем предсказуемого риска, подлежат изучению и внедрению на практике. Проанализированы особенности эффективных, цифровых технологий в сельском хозяйстве республики. В качестве ключевой проблемы отечественного аграрного сектора выделена низкая производительность и высокие издержки. Государственная политика Казахстана направлена на привлечение в страну ведущих мировых брендов сельхозтехники, созданных по инновационным нанотехнологиям, поддержку местных производств с объективно выполнимыми условиями локализации. Сделан вывод о необходимости применения высокотехнологичных методов для решения задач повышения урожайности сельскохозяйственных культур, продуктивности животных и произво-дительности труда, снижения производственных издержек.

Abstract. The key prerequisites for transition of domestic AIC to digital format of work are reflected. The vectors of influence of digital technologies on the development of agro-industrial complex are considered. Digital transformations in sectors of economy - first of all, the creation of a new industry by automating the country's transport and logistics system; the use of communication processes in agricultural sector, industry; e-commerce and improving systems for ensuring safety and availability of digital information, as well as implementation of these methods and techniques aimed to create "smart" cities. The authors note that digitalization is one of the most promising tools for achieving these goals. In addition, it should be understood that agribusiness in decision making is guided by such categories as increasing its profitability, expanding its market share, and increasing capitalization. In this direction, digitalization is one of the incentives for further development, because in competitive markets, any measures that can provide increase in profitability with acceptable level of predictable risk must be studied and implemented in practice. The features of effective digital technologies in agriculture of the republic are analyzed. Low productivity and high costs are highlighted as the key problems of domestic agricultural sector. The State policy of Kazakhstan is aimed at attracting the world's leading brands of agricultural machinery, produced using innovative nanotechnology, to the country, supporting local industries with objectively feasible localization conditions. It is concluded that it is necessary to use high-tech methods to solve the problems of increasing crop yields, animal productivity and labor productivity, and reducing production costs.

Түйінді сөздер: агроөнеркәсіптік кешен, инновациялар, жаңғырту, әртараптандыру, цифрлық технологиялар, электрондық сауда, бәсекеге қабілеттілік, өнімділік, рентабельділік, экономикалық талдау.

Ключевые слова: агропромышленный комплекс, инновации, модернизация, диверсификация, цифровые технологии, электронная торговля, конкурентоспособность, продуктивность, рентабельность, экономический анализ.

Key words: agro-industrial complex, innovation, modernization, diversification, digital technologies, e-commerce, competitiveness, productivity, profitability, economic analysis.

Kipicne. Жаңа жаһандық шындық жағдайында аграрлық сектордың жедел дамуына басымдық берілуде. Таяу уақытта ауыл шаруашылығы өнімдерін өндіру мен қайта өңдеу әртараптандырудың негізгі көзі және экономикалық өсудің драйвері болуы тиіс. АӨК-нің жаңа рөлі елдің тұрақты да- муын теңестіруге, еңбек өнімділігін және халықтың негізгі бөлігінің өмір сүру деңгейін арттыруға мүкіндік береді.

Елдің азық-түлік және ішінара экономикалық қауіпсіздігін қамтамасыз ететін ұлттық экономиканың маңызды секторы екені белгілі. Бірақ шешілмеген проблема- 
$\bullet \bullet \bullet \bullet \bullet \bullet \bullet \bullet \bullet \bullet \bullet \bullet \bullet \bullet \bullet \bullet \bullet \bullet \bullet \bullet \bullet$

лардың тұтас кешені де бар: ең алдымен бұл шикізат базасының дамуының жеткіліксіз деңгейі, бұл жаңа технологияларды, әсіресе цифрландыру элементтеріне негізделген, қолдану мүмкіндігінің болмауы есебінен өндіріс көлемін жедел ұлғайту бағамына сәйкес келмеуі және саланы жаңғыртудың және негізгі өндірістік қор-ларды жаңартудың төмен қарқыны.

Қазақстандағы цифрлық технологиялар ұлттық экономиканы әртараптандырудың, оны шикізаттан өнеркәсіптік қызмет көрсету моделіне қайта бағыттаудың негізгі әдісі ретінде қарастырылады.

Ел экономикасын цифрландыруды жеделдету үшін 2018-2022 жылдарға арналған «Цифрлық Қазақстан» Мемлекеттік бағдарламасы қабылданды, мұнда «цифрлық экожүйені үдемелі дамыту арқылы халықтың өмір сүру сапасын және Қа-зақстан экономикасының бәсекеге қабілет-тілігін жақсартуға болады» деген міндет қойылды. Мемлекет нақты технологияларды жедел дамыту арқылы елде «цифррлық секірісті» қамтамасыз ете алады.

Зертеу материалдары мен әдістері. Зерттеу барысында қарастырылып отырған мәселелер бойынша жүйелі көзқарастағы экономикалық зерттеулер әдістерінің кешені пайдаланылды. Жұмыстың әр түрлі кезеңдерінде аналитикалық, графикалық, экономикалық-статистикалық, абстрактілілогикалық, салыстырмалы зерттеу әдістері қолданылды:

-материалистік диалектика әдісі - құбылыс пен процестерді қозғалыс пен дамудағы, бір сапалы күйден екіншісіне ауысу кезіндегі зерттеу;

- ғылыми абстракция әдісі кездейсоқ, инценциалды абстракцияға негізделген және берілген экономикалық құбылыста тұрақты, типтік, маңызды табуға негізделген;

- анализ және синтез. Талдау әлеуметтік-экономикалық құбылыстарды олардың құрамдас бөліктеріне бөлуді және оларды зерттеуді көздейді. Синтез кезінде жеке бөліктер бір бүтінге біріктіріледі;

- индукция және дедукция. Индукция белгілі бір оқшауланған фактілерден жалпылама позицияларға өтуге мүмкіндік береді, ал дедукция жалпы ережелер негізінде нақты фрактілерді негіздеуге мүм-кіндік береді.

Нәтижелер және оларды талқылау. Ауыл шаруашылығын тиімді жүргізу үшін, сандық трансформацияның осы бағытында логистикалық-көліктік жүйелердің түйісу интерфейстері және тұтыну артықшылықтарын есепке алу мақсатында кері байла- ныс деректерін өңдеу жүйесі қажет. Бұл фрактор нақты қызмет саласының сандық өзгеру сценарийінде, интеграциялық құрылымдарды қалыптастыру жағдайында инно-вациялық шешімдерді қабылдау және іске асыру тәуекелдері жүйесінде коммерциялық емес бірлестіктердің рөлінің өсуіне және ауыл шаруашылығын басқарудың жеке-мемлекеттік цифрлық экожүйесін құру қажеттілігіне әкеледі.

Көптеген зерттеушілердің пікірінше, цифрландыру - аграрлық саланы дамытудың негізгі векторларының бірі. Біздің елімізде ауыл шаруашылығы өнімдерін өндірушілердің көпшілігін осындай жүйелердің сенімді пайдаланушылары деп атауға болмайды, алайда олардың көпшілігі оларға белсенді түрде қызығушылық танытады, сондай-ақ осы әзірлемелерді ұсынатын артықшылықтарға ие. Қазақстандағы цифрлық технология ұлттық экономиканы әртараптандырудың, оны шикізаттан индустриялық-сервистік модельге қайта бағдарлаудың негізгі жолы ретінде қарастырылады.

Ел экономикасын цифрландыруды жедел енгізу үшін арналған «Цифррлық Қазақстан» мемлекеттік бағдарламасы қабылданды, онда «цифрлық экожүйені прогрессивті дамыту арқылы халықтың өмір сүру сапасын және Қазақстан экономикасының бәсекеге қабілеттілігін арттыруға болады» деген міндет қойылды [1].

Осы бағдарламаны іске асыруға жалпы шығыстар 2017-2020 жылдары 384,2 млрд. теңгені құрайды. Ауыл шаруашылығы сияқты дәстүрлі салалар, атап айтқанда, өсімдік шаруашылығы мен мал шаруашылығындағы селекция мен клондау, қоршаған ортаға зиян келтіретін жаппай өндіріс пен тұтынуды қамтамасыз ететін бұрынғы маңызын жоғалтады. «Ақылды» агротехнологиялар ауысымына машиналық оқыту және нейросеталар, сандық платформалар, 3D баспа, робототехника, биосенсорлар және Big Data арқасында қамтамасыз етіледі [2].

Саланы жаңғырту мүмкіндіктері зор. Әлемдегі ауыл шаруашылығы дәстүрлі саладан жоғары технологиялық салаға айналады, ол бұрын көптеген практикалық міндеттерді шешу үшін болмаған инновациялық шешімдер мен әзірлемелер үшін жаңа нарықтар құруға қабілетті. Зияткерлік цифрлық шешімдер елдің ауыл шаруашылығына саладағы еңбек өнімділігін арттыру және оның тұрақты дамуы мәселелерін шешу уақыты келді. 


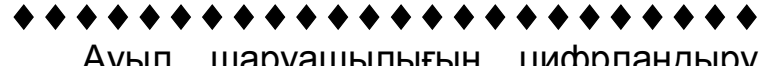
бүгінгі күні өте өзекті - бүкіл әлем бойынша жүздеген стартаптар негізделуде, жаңа сандық жүйелерді, оның ішінде өнеркәсіп пен аграрлық салада құруға бағытталған ұлттық және жаһандық жобалар пайда болуда, үлкен деректерді талдау жүзеге асырылуда және т.б. Осы жобалардың көпшілігіне орасан зор инвестициялар тарту мүмкіндігі фрактісі осындай идеялардың айқын көрінетінін және инвесторлар оларға - олардың іске асырылуы мен пайдалылығына сенетінін көрсетеді.

Осымен бір мезгілде біз соңғы уақытта ауыл шаруашылығында көбінесе бір-бірінен оқшауланған инновациялық шешімдердің көп саны жинақталғанын көріп отырмыз, осыған байланысты санның сапаға фразалық өзгеруін күту, яғни жеке «ақылды» элементтер мен тораптардан шаруашылықтарды толассыз цифрландыру жүйесіне көшу бар. Бірақ уақыт жүріп жатыр, ал мұндай процесс байқалмайды. Осы себепті біртіндеп бұл құбылыстың кейбір шектеулері бар екенін түсіну келеді, олар бізді бастапқыда көрінгеннен гөрі мұқият қарауға мәжбүр етеді. Мұндай тежеуші факторлардың бірі - инфррақұрылым.

АӨК-дегі цифрландыру: тәуекелдерді азайтуға, климаттың өзгеруіне бейімделуге, ауыл шаруашылығы дақылдарының өнімділігін және жануарлардың өнімділігін арттыруға, дала жұмыстарын уақтылы жоспарлауға мүмкіндік береді. Ресурстарды және ғылыми негізделген тәсілдерді тиімді пайдалану негізінде өнімді өндіруге жұмсалатын шығындарды төмендету, оның сапасы мен бәсекеге қабілеттілігін арттыру бұл ауыл шаруашылығын цифрландырудың басты міндеті. Ауылдық тауар өндірушілерді қажетті ақпаратпен қамтамасыз ету сатып алу мен сатуға транзакциялық шығындарды азайтуға, өнімді егіс алқабынан тұтынушыға дейін жеткізу тіз- бегін жеңілдетуге, білікті жұмыс күшіндегі тапшылықты қысқартуға мүмкіндік береді.

2012 жылы «Қазақстан-2050: стартегиясы қалыптасқан мемлекеттің жаңа саяси бағыты» ұлттық даму стратегиясы айтылды, осыған байланысты «Ақпараттық Қазақстан-2020» мемлекеттік бағдарламасы бекітілді. Қолданыстағы «Ақпараттық Қазақстан-2020» мемлекеттік бағдарламасының негізгі бағыттары халық үшін ақпараттық-коммуникациялық инфррақұрылымның қолжетімділігін қамтамасыз ету, телекоммуникация саласын дамыту, елдің барлық ірі қалаларында оңтайлы қол жеткізу желілерін құру, халықты жоғары жылдамдықты интернетпен қамтамасыз ету болып табылады [3].

Бағдарламада көзделген іс-шараларды қаржыландыру көлемі ҚР заңнамасына сәйкес тиісті қаржы жылдарына арналған республикалық және жергілікті бюджеттерді бекіту кезінде нақтыланатын болады.

Аграрлық-өнеркәсіптік кешен (АӨК) дамытуға жалпы қаржыландырудың қажетті көлемі 2020 жылға қарай 2015 жылмен салыстырғанда 1,2 есе өсті, ал облигациялық қарыздарды, «Азық-түлік келісімшарт корпорациясы» Акционерлік қогам мен «Қазагро «Ұлттық басқарушы холдингі» (ҰБХ) Акционерлік қоғам меншікті қаражатын ескермегенде бюджеттік қаржыландыру көлемі 2 есе өсті және 382,7 млрд. теңгені құрады. АӨК субъектілерін қаржылық сауықтыру жөніндегі іс-шаралар облигациялық қарыздар, республикалық бюджет және Ұлттық қор қаражаты есебінен жүзеге асырылатын болады, олардың көлемі 591,3 млрд.теңгені құрайды [4].

Аграрлық-өнеркәсіптік кешен АӨК субъектілері үшін тауарлардың, жұмыстардың және қызметтердің қолжетімділігін арттыру Бағдарламаны қаржыландырудың жалпы көлемінде 2,5 есе өсті ( 1 кесте).

1 кесте - Бағыттар бойынша қаржыландырудың қажетті көлемі, мың теңге

\begin{tabular}{|l|c|c|}
\hline \multicolumn{1}{|c|}{ Бағыттар } & 2015 ж. & 2019 ж. \\
\cline { 2 - 3 } & $\begin{array}{c}\text { Қаржыландыру } \\
\text { көлемі, мың теңге }\end{array}$ & $\begin{array}{c}\text { Қаржыландыру } \\
\text { көлемі, мың теңге }\end{array}$ \\
\hline АӨК субъектілерін қаржылық сауықтыру & 157980000 & 21988600 \\
\hline $\begin{array}{l}\text { АӨК субъектілері үшін тауарлардың, жұмыс-тардың және } \\
\text { көрсетілетін қызметтердің қолжетімділігін арттыру }\end{array}$ & 127865830 & 321229227 \\
\hline АӨК субъектілерін мемлекеттік қамтамасыз етуді дамыту & 51123538 & 49318385 \\
\hline АӨК мемлекеттік реттеу жүйесінің тиімділігін арттыру & 2747728 & 4203257 \\
\hline Барлығы & 339717096 & 396739469 \\
\hline $\begin{array}{c}\text { Ескертпе - Қазақстан Республикасы Ұлттық экономика министрлігі Статистика комитеті } \\
\text { мәліметтері негізінде құрастырылған. }\end{array}$ \\
\hline
\end{tabular}




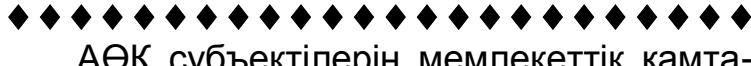
масыз етуді дамытуға бөлінген қаражаттың және мемлекеттік реттеу жүйесінің тиім- ділігін арттыруға арналған шығыстардың үлесі 2019 жылы 2015 жылмен салыстырғанда 20\% - ға ұлғайды (2 кесте).

2 кесте - Қаржыландыру көздері бөлінісінде бюджеттік қаржыландырудың қажетті көлемі, мың теңге

\begin{tabular}{|c|c|c|c|c|}
\hline \multirow[b]{2}{*}{$\begin{array}{c}\text { Қаржыландыру } \\
\text { көздері }\end{array}$} & \multicolumn{2}{|c|}{2015 ж. } & \multicolumn{2}{|c|}{2019 ж. } \\
\hline & $\begin{array}{c}\text { Бюджеттік } \\
\text { қаржыландыру } \\
\text { көлемі, мың } \\
\text { теңге } \\
\end{array}$ & $\begin{array}{c}\text { Мемлекеттік } \\
\text { бюджеттегі бюд- } \\
\text { жеттердің үлесі, } \\
\% \\
\end{array}$ & $\begin{array}{c}\text { Бюджеттік қаржы- } \\
\text { ландыру көлемі, } \\
\text { мың теңге }\end{array}$ & $\begin{array}{c}\text { Мемлекеттік } \\
\text { бюджеттегі } \\
\text { бюджеттердің } \\
\text { үлесі, \% } \\
\end{array}$ \\
\hline $\begin{array}{l}\text { Республикалық } \\
\text { бюджет }\end{array}$ & 156295487 & 85 & 355346330 & 93 \\
\hline Жергілікті бюджет & 28266609 & 15 & 27393139 & 7 \\
\hline $\begin{array}{l}\text { Бюджеттік қаржы- } \\
\text { ландыру жиыны }\end{array}$ & 184562096 & 100 & 382739469 & 100 \\
\hline
\end{tabular}

Мемлекеттік бағдарлама мынадай бағыттардан тұрады: Сандық Жібек жолы, креативті қоғам, экономика салаларындағы сандық өзгерістер. Цифрлық Жібек жолыауылдық елді мекендерде интернетке кең жолақты қолжетімділікті жүргізу, телекоммуникациялық хабты дамыту, ақпараттық қауіпсіздікті қамтамасыз ету, деректерді өңдеу орталықтарын салу арқылы жоғары технологиялық цифррлық инфрақұрылымды құру. Креативті қоғам - халықтың цифррлық сауаттылығын арттыру, ақпараттық-коммуникациялық технологиялар саласындағы мамандардың біліктілігін арттыру, креативті ойлауды дамыту арқылы адами капиталды дамыту.

Елдің экономика салаларындағы цифрлық қайта құру, көліктік-логистикалық жүйесін автоматтандыру, ауыл шаруашылығы, өнеркәсіп саласында цифрлық технологияларды енгізу, электрондық сауданы дамыту, минералдық ресурстарды есепке алу жүйесін жақсарту, геологиялық цифррлық ақпараттың сақталуы мен қолжетімділігін қамтамасыз ету, «ақылды» қалаларды құру үшін технологияларды іске асыру жолымен цифрлық индустрияны дамыту.

Сондықтан цифрландыру осы мақсатқа жетудің ең перспективалы құралдарының бірі болып табылады.

Бұдан басқа, агробизнес шешімдер қабылдауда жалпы адамзаттық проблемаларды шешудің міндеттерін емес, неғұр-лым маңызды санаттарды бизнестің рен-табельділігін арттыруды, нарықтың өз үле-сін кеңейтуді, капиталдандырудың өсуін және басқаларды басшылыққа алатынын түсіну керек.
Бұл бағытта цифррландыру одан әрі дамуды ынталандырудың бірі болып табылады, өйткені бәсекелестік нарықтарда болжанатын тәуекелдің қолайлы деңгейімен пайданы ұлғайтуды қамтамасыз етуге қабі-летті кез келген шешім зерделеуге және енгізуге жатады. Осындай жағдайда әрекет ететін қарапайым ереже: егер бүгін сіз биз-несіңіздің өндірістік тиімділігін арттыру үшін әрекет жасамасаңыз, ертең бұл шешімді сіздің бәсекелесіңіз жасайтын болады.

Сандық жүйелер параметрлерді автоматтандыру есебінен техниканы анағұрлым нәтижелі пайдалануды қамтамасыз етеді, әр түрлі мәліметтерді оңтайландыру мақсатында деректердің үлкен массивіне талдау жүргізуге мүмкіндік береді, мысалы, енгізілетін тыңайтқыштар, кәсіпорынның жалпы KPI-i, ауа райы, өнімділік және т.б. туралы, өндірістік шығындарды азайту және шектеулі ресурстарды неғұрлым ұтымды пайдалану.

Цифррландыруға байланысты инновациялардың құны айтарлықтай жоғары және ауыл шаруашылығы тауарын өндірушілердің барлығы оларды, әсіресе шағын фрермерлік шаруашылықтар мен шаруа қожалықтарын сатып алуға мүмкіндігі жоқ екенін атап өткен жөн. Ол инновацияны тарату, оларды көбейту және қолдану тұрғысынан экономиканың инновациялық дамуының мүдделі субъектісі ретінде мемлекеттің қатысуынсыз бола алмайды [5].

Қазақстан Республикасы Тұңғыш Президентінің 2017 жылғы 31 қаңтардағы «Қазақстанның үшінші жаңғыруы: жаһандық бәсекеге қабілеттілік» атты жыл сайынғы Жолдауында Қазақстан Республикасының 


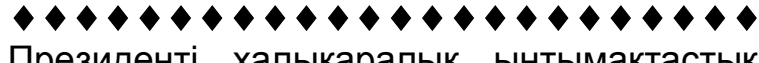

Президенті халықаралық ынтымақтастық шеңберінде Ұлттық экономикалық мүдделерді, ең алдымен, Еуразиялық экономикалық одақты (ЕЭО) ішіндегі жұмысты қорғауды және ілгерілетуді қамтамасыз ету қажеттігі туралы атап өтті [6].

Президент экономиканың аграрлық секторына баса назар аударды, өйткені Қазақстанның агроөнеркәсіп кешенінің болашағы зор. Көптеген ұстанымдар бойынша Қазақстан әлемдегі ең ірі аграрлық экспорттық өнім өндірушілердің бірі бола алады, әсіресе бұл экологиялық таза азықтүлік өнімдерін өндіруге қатысты. «Made in Kazakhstan» бренді мұндай өнімнің эталоны болуы тиіс [7].

Қазақстанның АӨК-де жаңа мемлекеттік ақпараттық жүйелерді құрумен және қолданыстағыларын дамытумен қатар, ауыл шаруашылығы құрылымдарында автоматтандырылған жүйелерді құру және енгізу жөніндегі шарт міндетті және маңызды болып табылады. Әлемнің барлық жетекші аграрлық елдерінің тәжірибесі осындай тәсілдің даусыз үлгісі болып табылады.

Ауыл шаруашылығы өндірісіндегі және өңдеудегі барлық көптеген үдерістер үшін көптеген ат шешімдері тікелей және негізгі дәрежеде бизнесті жүргізу тиімділігіне, еңбек өнімділігін арттыруға, тиімділікке және агроөнеркәсіп кәсіпорындарының бәсекеге қабілеттілігіне, ұсақ фермерлік шаруашылықтан ірі агроқұрылымдарға дейін әсер етеді.
Отандық ауыл шаруашылығы өнімдерінің және оны қайта өңдеу өнімдерінің бәсекеге қабілеттілігін арттыру отандық өнімді ішкі нарықта да, экспорттық нарықтарда да жылжыту және позициялау қажеттігімен тығыз байланысты.

Еуразиялық даму банкіне қатысушы елдердің сандық әлеуетіне талдау жүргізу кезінде олардың экономикалық құрылымының ерекшелігін, бірінші кезекте Еуразиялық даму банкіне қатысушы бірқатар елдердің негізгі салаларының бірі ретіндегі ауыл шаруашылығының маңызын ескеру өте маңызды.

Бір қарағанда, экономикадағы цифрландыру мен технологиялық серпіліс ауыл шаруашылығы секторының қарама-қайшы дамуы, өйткені технологияларды енгізу нәтижесінде адам ресурстарына сұраныс төмендейді және осылайша, осы сектордағы жұмыспен қамту азаяды. Алайда, әлемдік тәжірибе көрсеткендей, үздіксіз технологиялар ресурстарды тиімді пайдалануға ықпал ете отырып, ауыл шаруашылығын құрылымдық жағынан өзгерте алады.

Еуразиялық даму банкіне қатысушы елдердің ЖІӨ-дегі ауыл шаруашылығының үлесін салада жұмыс істейтін жұмыспен қамтылған халықтың үлесімен салыстыру Беларусь пен Ресейден басқа, бұл сектор жеткілікті төмен өнімділікпен сипатталады. Мұнда жұмыспен қамтылған халықтың $50 \%$-дан астамы ЖІӨ-нің 20\%-ын ғана өндіретін салада жұмыс істейді (сурет).

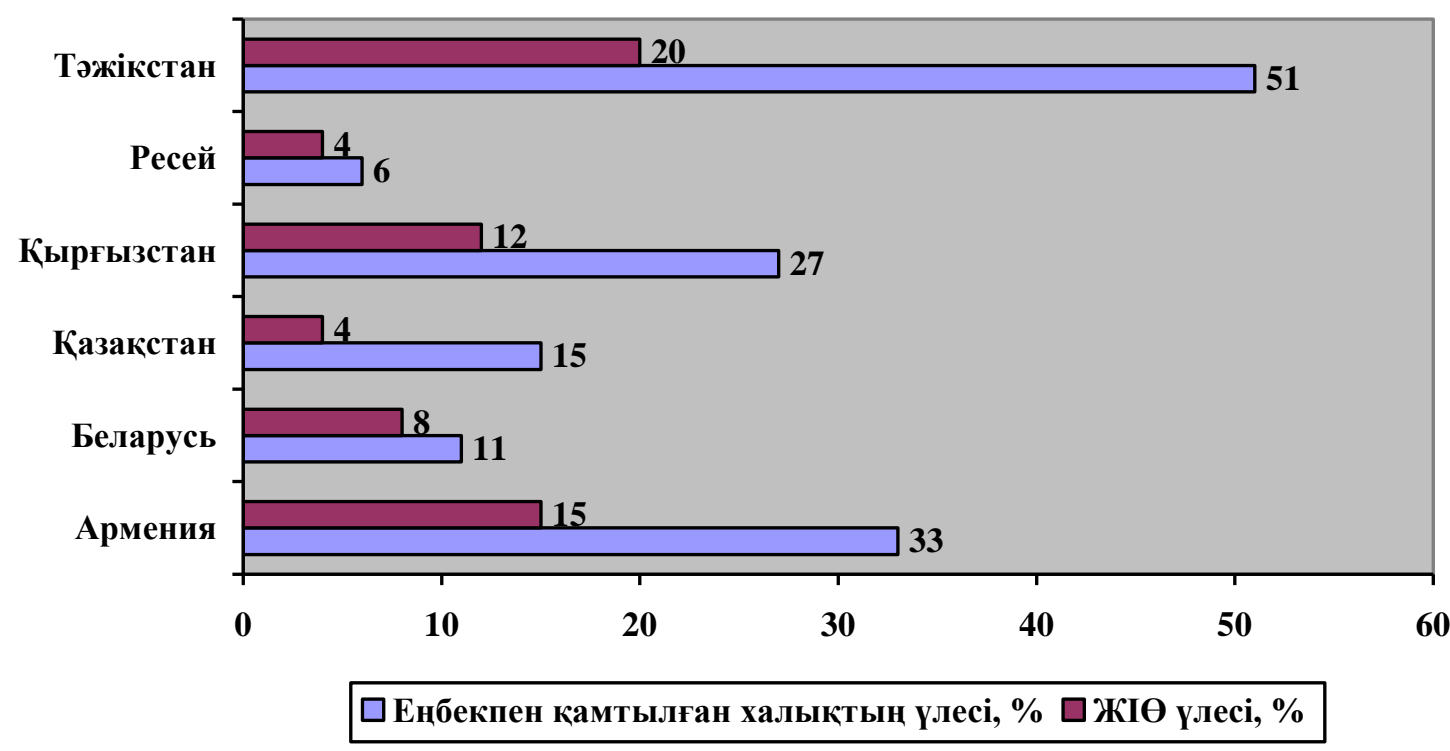

Сурет - Еңбекпен қамтылғаң халықтың үлесі (ЕҚХY елдерінің ЖІӨ-дегі ауыл шаруашылығының үлесі және 2019 жылы ауыл шаруашылығы саласында жұмыспен қамтылған халықтың үлесі, \% 
$\bullet \bullet \bullet \bullet \bullet \bullet \bullet \bullet \bullet \bullet \bullet \bullet \bullet \bullet \bullet \bullet \bullet \bullet \bullet \bullet \bullet$

Еңбекпен қамтылғаң халықтың үлесі ЕҚХY өткізген цифррлық Ауыл шаруашылығын дамыту жөніндегі 15 елдің тәжірибесін талдау мемлекеттік және жеке секторлар арасындағы ынтымақтастықты дамыту жөніндегі күш-жігер қарастырылған көптеген елдерде белсенді түрде қабылданғанын растайды [8].

Бұдан басқа, талдау осы саладағы халықаралық ынтымақтастықтың маңыздылығын атап көрсетеді, өйткені ол шығындарды қысқартуды, ресурстарды біріктіруді және ауыл шаруашылығы саласындағы өңірлік және жаһандық проблемаларды шешу үшін синергетикалық әсерді пайдалануды білдіреді.

Еуразиялық кеңістікте цифрлық ауыл шаруашылығы бағыты әлі ерте даму кезеңінде, көптеген елдердің осы салада ұлттық стратегиялары жоқ, бірақ бағаларына сәйкес Халықаралық азық-түлік ауыл шаруашылығы ұйымы айтарлықтай әлеуетке ие. Қазіргі уақытта қатысушы елдерде сандық ауыл шаруашылығы бойынша ең озық министрлік жобалардың бірі Ресей Ауыл шаруашылығы министрлігі әзірлеген болатын.

ЕО көптеген елдерінде сандық технологияларды енгізу мәселесі аграрлық саланы дамытудың жаңа форматтары үшін неғұрлым қолайлы және өзекті заңнамалық шеңберлерді қамтамасыз етуге тырысатын фермерлер мен салалық одақтар, сондайақ реттеуші органдар да бұрыннан талқылануда. 2019 жылы Verband Deutscher Maschinen und Anlagenbau (VDMA) Landtechnik қауымдастығы Германия Ауыл шаруашылығы министрлігімен бірлесіп «ауыл шаруашылығындағы цифрландыру» диалог платфрормасын іске қосты. Оның негізгі міндеттері - пилоттық цифрллық фрермаларды және геодеректердің біріздендірілген ұлттық базасын құрумен байланысты практикалық мәселелерді пысықтау.

Тұтастай алғанда, агроөнеркәсіптік кешенді инновациялық дамытуға және ауыл шаруашылығы өнімдерін өткізуді ынталандыруға бағытталған мемлекеттік саясат саладағы оң үрдістерге ықпал етеді, алайда АӨК субъектілерінің одан әрі күш-жігерін талап ететін бірқатар проблемалар бар екенін атап өткен жөн.

Аграрлық секторды жаңғырту және инвестициялық тартымдылық мәселелері агроөнеркәсіптік кешен инфрақұрылы-мының жай-күйімен үнемі байланысты. Сонымен бірге инфрақұрылымның негізгі буындары (өнімді дайындау және сақтау, көлік коммуникациялары, көтерме сауда нарықтары, биржалық құрылымдар және т.б.), сондайақ аграрлық өнім нарығының ақпараттық инфррақұрылымын дамыту рефрормалануда, агроөнеркәсіптік кешен ин-фррақұрылымын қалыптастыруда маңызды бағыт болып отыр [9].

Аграрлық-өнеркәсіптік кешен (АӨК) жаңа технологияларды енгізудің жылдамдығы мен тиімділігі пайдаланылатын ауыл шаруашылығы техникасымен тығыз байланысты және оның инновациялылығы, өнімділігі мен сенімділігі деңгейіне байланысты екені анық. Бүгінде Германия қазіргі заманғы ауыл шаруашылығы машиналарын өндіруде әлемдік көшбасшылардың бірі болып табылады, сондықтан көптеген компаниялар аграрлық саладағы цифрллық технологияларды дамыту жөніндегі жұмысқа белсенді қатысуда.

Ауыл шаруашылығын сандық трансформациялау арқылы келесі міндеттерді шешуге болады:

- еңбек өнімділігін арттыру;

- салада жаһандық жоспарлауды қамтамасыз ету және нарық қатысушыларына нақты ұсыныстар беру және өңірлердің ақпараттық ресурстарын ықпалдастыру;

- аймақтық АӨК (АӨК) сандық технологияларды енгізу үшін қолдау шаралары мен тетіктерін қалыптастыру мақсатында ауыл шаруашылығы тауар өндірушілері үшін мемлекеттік сервистер мен порталдарды ұсыну;

- аграрлық-өнеркәсіптік кешен (АӨК) кәсіпорындарының мемлекеттік, банктік және сақтандыру өнімдеріне қол жеткізуін қамтамасыз ету үшін цифрлық ауыл шаруашылығы платформасының функционалын интеграциялау және өзара іс-қимылдың кері схемасын әзірлеу;

- ауыл шаруашылығы шикізатын, сондай-ақ түпкілікті өнімді (тауарды) бақылау негізінде шаруашылықтар мен тұтынушы-лар үшін аграрлық нарықтардың ашықты-ғын арттыру үшін жағдай жасау;

- отандық әзірлемелерді ынталандыру және ауыл шаруашылығы тауарын өндірушілер мен әзірлеушілерге түрлі цифррлық ашық платорормаларға қол жеткізуді қамтамасыз ету.

Тұжырымдар. 1. Осылайша, Еуразиялық экономикалық одақ тұтастай алғанда экономиканы дамыту үшін және атап айтқанда Аграрлық-өнеркәсіптік кешен (АӨК) үшін ерекше институционалдық жағдайлар жасайды. Бір жағынан, тауар нарықтарының шекаралары кеңеюде, екінші жағынан, оның ішінде ішкі қазақстандық нарықта бәсекелестік күшейе түсуде. Бұл тамақ 


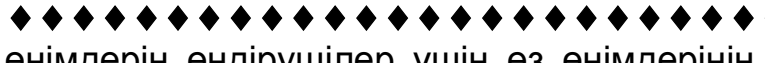
өнімдерін өндірушілер үшін өз өнімдерінің сапасын арттыруға жаңа сыртқы ынталандырулар жасайды және өндірушілерді мемлекеттік қолдау бағдарламаларының барлығы, олардың қызметін шаруашылық жүргізудің жаңа технологияларын жаңғыртуға және игеруге бағдарланғаны үшін мемлекетке жауапкершілік жүктейді.

2. Сонымен қатар, шешім қабылдау кезінде агробизнес жалпы адамзаттық мәселелерді шешу міндеттерін басшылыққа алмайтынын, бірақ неғұрлым өзекті категориялар - бизнестің рентабельділігін арттыру, оның нарықтағы үлесін кеңейту және капиталдандыруды ұлғайту туралы түсіну керек.

3. Сандық жүйелер қондырғыларды автоматтандыру есебінен жабдықтың тиімдірек жұмыс істеуін қамтамасыз етеді, әр түрлі ақпараттарды оңтайландыру үшін көптеген мәліметтерді талдауға мүмкіндік береді, мысалы, енгізілген тыңайтқыштар туралы, кәсіпорынның жалпы КPI, ауарайы, кірістілік және басқалар, өндіріс шығындарын азайту және шектеулі пайдалану ресурстары.

4. ЕО-ның көптеген елдерінде цифрлық технологияларды енгізу мәселесі фермерлермен де, салалық кәсіподақтармен де, аграрлық секторды дамыту үшін жаңа форматтар үшін ең қолайлы және өзекті заңнамалық базаны ұсынуға тырысатын реттеушілермен де көптен бері талқыланып келеді.

5. Агроөнеркәсіптік кешенге жаңа технологияларды енгізу тиімділігі қолданылатын ауыл шаруашылық техникаларымен ажырамас байланысты және оның жаңашылдық деңгейіне, өнімділігі мен сенімділігіне байланысты.

\section{әдебиеттер тізімі}

1 Государственная программа «Цифровой Казахстан» на 2017-2020 годы от 12 декабря 2017 года № 827 / [Электронный ресурс]. -2017.- URL: http://www.economy.gov.kz (дата обращения 13.09. 2019).

2 Аганбегян, А.Г. Устойчивый рост сельского хозяйства и его финансовое обеспечение / А.Г. Аганбегян // Деньги и кредит. 2017. - № 7. - С. 3-9.

3 Муканова, А. Цифровизация как путь к успеху/ А. Муканова // Казахстанская правда.2017. -14 сентября.

4 Программы по развитию агропромышленного комплекса в Республике Казахстан «Агробизнес-2017» [Электронный ресурс]. 2013.- URL: http://www.online.zakon.kz (дата обращения 26.09. 2019).
5 Вартанова, М.Л. Перспективы цифровизации сельского хозяйства как приоритетного направления импортозамещения/ М.Л. Вартанова, Е.В. Дробот // Экономические отношения. - 2018. - Том 8. - № 1. - С. 1-18.

6 Послание Первого Президента Республики Казахстан Н.Назарбаева народу Казахстана от 31 января 2017г. «Третья модернизация Казахстана: глобальная конкурентоспособность» [Электронный ресурс]. - 2017.URL: http//www.akorda.kz (дата обращения 07.09. 2019).

7 Программа по развитию агропромышленного комплекса в Республике Казахстан «Агробизнес-2017» [Электронный ресурс]. 2017.- URL: http://www.online.zakon.kz (дата обращения 26.09.2019).

8 Байгабулова, К.К. Цифрландыру Қазақстан Республикасының сүт саласының инновациялық даму факторы ретінде / К.К. Байгабулова, Е.А. Ахмедьяров, Г.К. Алтыбаева // Проблемы агрорынка. - 2019. - №2. Б.146-151.

9 Чкония А., Мешков И.А. Состояние кластерного развития В государствах участниках ЕАБР [Электронный ресурс]. 2019.- URL: //http://www.eabr.org (дата обращения 10.10. 2019).

\section{References}

1 State program "Digital Kazakhstan" for 2017-2020 of December 12, 2017 No. 827 / [Electronic resource]. -2017.- URL: http://www.economy.gov.kz (date of access 13.09.2019).

2 Aganbegyan, A.G. Sustainable growth of agriculture and its financial support / A.G. Aganbegyan // Money and Credit.- 2017. - No. 7. - P. 3-9.

3 Mukanova, A. Digitalization as a path to success / A. Mukanova // Kazakhstanskaya Pravda.- 2017. -14 September.

4 Programs on agro-industrial complex development in the Republic of Kazakhstan "Agrobusiness-2017" [Electronic resource]. -2013URL: http://www.online.zakon.kz (date of access: 26.09.2019).

5 Vartanova, M. L. Prospects for the digitalization of agriculture as a priority direction of import substitution / M.L. Vartanova, E.V. Drobot // Economic Relations. - 2018. - Volume 8. - No. 1. - P. 1-18.

6 Message of the First President of the Republic of Kazakhstan N. Nazarbayev to the people of Kazakhstan dated January 31, 2017. "The third modernization of Kazakhstan: global competitiveness" [Electronic resource]. - 2017.URL: http // www.akorda.kz (date of access 07.09.2019).

7 Program on agro-industrial complex development in the Republic of Kazakhstan "Agro- 